\title{
Globalization, Power, and Security
}

\author{
SEAN KAY* \\ Ohio Wesleyan University, Delaware, OH, USA
}

This article surveys major international relations theory as a framework for thinking about globalization; examines the modern role of power within a globalized international system; and illustrates these dynamics within the context of international terrorism. The central conclusion is that globalization has not radically changed fundamental aspects of international relations, but has rather altered means and channels for the exercise of power. The article demonstrates that power remains the key independent variable shaping modern international relations. Globalization is a manifestation of new means through which power is exercised and distributed. Nevertheless, the complexity of globalization requires a reassessment of the meaning of power in international security.

Keywords asymmetric power - globalization $\cdot$ hard and soft power - power $\cdot$ security $\cdot$ terrorism

$\mathrm{I}$ N A WORLD DEFINED BY GLOBALIZATION, new sets of complex and interrelated risks force states to redefine their security needs. This article demonstrates that, in spite of the globalization upheaval, a key independent variable of international relations remains constant - power. The relative distribution of power and the means through which it is disseminated are central to understanding globalization. Analysis that treats globalization as an independent phenomenon ignores the role of globalization as a channel for the exercise of power. Globalization has not radically changed international relations, but has rather altered the means through which international security relationships are channeled. This article surveys major theories of international relations as signposts to understanding globalization; assesses new forms that power takes in international relations; and examines these issues within the context of international terrorism. What makes the search for security in a globalized world new is the means through which international power flows. 


\section{International Relations Theory and Globalization}

Globalization is often seen by its proponents as facilitating a new idealism of economic openness, political transparency, and global culture. Globalization provides an opportunity for the advancement of common human standards and equality as norms and rules are channeled throughout the world. This global proximity is thought to foster cooperation and to increase security. Alternatively, globalization is often seen as a tool for large hegemonic states to exercise economic primacy with little regard for human rights, labor standards, or the environment. In this context, globalization is a threat which must be organized against. States may seek to defend against the 'threat' of globalization as individuals organize to 'combat' the perceived dangers of globalization.

This article demonstrates that globalization is a neutral force through which power is channeled. Globalization is best understood as the creation of a variety of transboundary mechanisms for interaction that affect and reflect the acceleration of economic, political, and security interdependence. As states increasingly feel the effects of globalization, particularly in the economic sphere, it has become paramount for international relations theory to account for the international structure of globalization. For example, as the Asian financial crisis of 1997-98 showed, close international economic interdependence can increase vulnerability across borders. This outcome became especially clear to authoritarian regimes who could not sufficiently adapt to the pressures of economic and financial globalization without risking their hold on state power. Countries like Indonesia have witnessed significant economic pressures for governmental reform. The desire of China to reap relative economic gains via international trade has clashed with its internal human rights record and its management of transnational diseases such as SARS and HIV / AIDS. Additionally, China's quest to join the World Trade Organization has forced it to adapt to certain international norms of trade espoused by its Western partners.

Much of the study of globalization focuses on the measurement of economic interdependence and related vulnerabilities or opportunities. However, the terrorist attacks of 11 September 2001 necessitate a hard look at existing analytical frameworks for understanding the relationship between globalization and security if adequate international responses are to be achieved. If it is difficult to define globalization, it is even more difficult to make a precise conclusion as to how globalization increases or decreases the degree of security (Clark, 1999). If security is the quest for the absence, or lessening, of threats in an anarchic world, globalization might increase or decrease security outcomes. If security is seen as a particularistic quest of nation-states to provide for their own defense, then globalization also provides both challenges and opportunities. 
Scholars can directly measure economic globalization by observing various flows of economic transactions. Measuring the relationship between globalization and international security is more difficult. It is not entirely necessary to come up with a perfect definition of security globalization - rather, we need to accept that it has occurred and to understand its effects and causal relationships. What makes globalization such a crucial aspect of modern international security is that the phenomenon brings an entirely new set of measurements of international security layered on top of those that dominated 20th-century global politics. Globalization does not represent a transformation of the international system. It represents an adaptation of the means through which international interactions are exercised, combined with an increase in the number and types of actors. One can know that globalization exists and matters as part of the structure of international relations because of the effects that it produces. A close look at these effects demonstrates that globalization is neither an independent nor a causal phenomenon. Rather, globalization is best understood as a technologically facilitated proliferation of the means through which power within the international system is channeled and pursued. What make globalization a new, and essential, component of contemporary international security are the increasingly complex conditions under which international actors exercise power.

The classical approach to the study of international relations, realism, focuses on the nation-state as a barrier between the international system and the domestic sphere of politics. Domestic politics are seen as separated from the international system, which is characterized as anarchy or the absence of order. Realists focus on the nation-state (especially its military and economic capabilities) and the desire of states to advance national interests and gains (both absolute and relative). In this view, states are fundamentally concerned with survival and seek to maximize power toward this end. States must ensure that they can provide for their military and economic safety, and they cannot count on the goodwill of others. Institutions such as international law and formal international organizations might be useful as tools for advancing national interests and exerting power, but they are not to be relied upon for security guarantees (Mearsheimer, 1995). To realists, globalization reflects the hegemonic influence of the major powers in international politics. Realists tend to see proximity creating vulnerability, which leads to conflict (Waltz, 1979; Mearsheimer, 2001).

Globalization, however, is more complicated than realist theory alone can account for. If globalization is measured as the acceleration of transboundary communication, international networks, the diffusion of power, reciprocity and mutual dependence, and the expansion of universal norms and principles, a different conclusion about contemporary international politics emerges. These trends combine with the proliferation of non-state actors such as formal international organizations, nongovernmental organizations, 
and multinational corporations - to alter the playing field of international relations. Neoliberal institutional theory explains international relations in terms of complex interdependence, and considers these new international dynamics as positing a serious challenge to realism (Keohane \& Nye, 2001). Neoliberal institutionalism focuses on the unique conditions of globalization that reflect accelerating interdependence and its impact on how states perceive their interests (Keohane, 2002). In a condition of complex interdependence, states will recognize a mutual demand for cooperation. Neoliberal institutionalists recognize the same vulnerability and sensitivity of interdependence that realists do. However, rather than seeing globalization as breeding conflict, neoliberal scholars see states as having an interest in cooperation (Keohane, 1989). States will share an interest in creating international institutions to facilitate cooperation, and new actors will emerge that affect international agenda-setting, while power becomes more diffused. Traditional measurements of power - such as military capabilities - will become less valuable to states as they prioritize long-term benefits from cooperation over short-term tactical advantage (Keohane \& Nye, 2001). In recognizing a state-based interest in collectively managing a globalized world, states seek to reduce coordination problems, to establish agreed principles, norms, rules, and decisionmaking procedures, to facilitate transparency, to increase the capacity for bargaining and issue-linkage, to enhance socialization toward an international community, and to lower the transaction costs of collective action.

Another major school of international relations theory, constructivism, draws on social theory of human interaction and posits that the structure and content of international relations are the by-products of social interaction (Wendt, 1994). In this sense, not all states are alike; rather, states reflect the social structures around which their peoples coalesce. Just as the domestic content of politics and culture shapes the identity of the nation-state, so does the nation-state simultaneously shape the international environment (Wendt, 1999). The international environment thus becomes a reflection of the intersocial relationships among states, and at the same time can feed back to influence the domestic content of nation-states. For example, constructivists assert that the Cold War ended not because of a shift in the distribution of power, but because of the power of the new ideas cultivated by reformist leaders within the Soviet Union (Wendt, 1992). Consequently, 'interest' and 'power' only have meaning if society gives such concepts value. Power thus takes on a variety of contexts so that the content of values, principles, and norms can define how states perceive their interests and how they perceive (and are perceived by) other states. The emphasis that constructivism places on ideas and learned perceptions within a normative context is a very useful means of understanding the embedded norms of the international system (Goldstein \& Keohane, 1993). 
These major paradigms of international relations provide an important basis for examining the relationship between globalization and security. Realists demonstrate that power matters and that there remain some key common goods that only the nation-state can supply - though realists are challenged to think harder about how power matters and how best to understand the new realities of global politics (Brown, 1998). The neoliberal institutionalist school shows that the international system is increasingly complex and that states alone cannot fully provide for their own security. Neoliberals are, nevertheless, challenged to demonstrate exactly how cooperation can best be achieved. Constructivists remind observers that international relations are a battle not just of power, interests, and agenda-setting - but also of ideas. The importance of material and economic gains and hegemony only have meaning in so far as they are ideas given meaning by people and societies. Consequently, people and societies have power to seek positive or negative change for the future of globalization.

From these theoretical approaches to international relations, it is possible to delineate between the risks and opportunities that globalization provides for security provision. Realism suggests that globalization will breed suspicion, vulnerability, and conflict because the more interdependent people and states become, the more insecure they will be (Waltz, 1979). Realism also suggests that the content of globalization reflects the relative distribution of power and favors the dominant international actors. Alternatively, neoliberal institutionalism proceeds from a basic optimism that managing globalization requires multilateral cooperation and states will define their quest for power in terms of mutual gains. Constructivists help observers recall the importance of identity and reinforce the fact that, while states matter, so does culture. Cultures and civilizations might clash, or cultures might blend and share common ideals and objectives (Huntington, 1996). These major theories of international relations share an emphasis on the role of power - though each comes to different conclusions as to its meaning and consequences. Each analytical approach helps students, scholars, and policymakers to understand that the quest for power holds within it the potential for both security and insecurity, for both war and peace. Understanding the new means of exercising power via globalization is thus one of the most fundamental challenges for international relations theory and practice of the 21st century.

\section{The Evolving Meaning of Power}

Power has historically been measured in terms of military capabilities, economic strength and natural resources, and the capacity to transform these 
assets into the exertion of influence. In the classic sense, power is the ability to get someone to do something that they otherwise would not do (Morgenthau, 1978; Keohane \& Nye, 2001). In security terms, the distribution of power has been central to understanding war and peace. A disequilibrium of power might lead to competitive arms races and wars, and a stable balance of power could prevent war. Traditionally, the central measure of power in the security context is derived from military capabilities - assessed in either offensive or defensive terms (Claude, 1962; Levy, 1983; Walt, 1987; Glaser \& Kaufman, 1998; Van Evera, 1999). The traditional understanding of power views it as a means to an end - though the quest for power can also become an end in and of itself. Regardless of the reasons for attaining power, the standard reply to the question 'What is the nature of the international system?' has been the further question 'Where lies the distribution of power?'

Globalization forces states to reconceptualize the meaning of power (Kugler \& Frost, 2001; Tangredi, 2002). Realists have done this by emphasizing both the material gains states make internationally and relative capabilities. Economic development and capacity, educated publics, and technological advances all can be measures of power that increase the capacity of a state to transfer latent capabilities into actual military power. As neoliberal institutional scholars demonstrate, under conditions of interdependence, power becomes diffuse - and it works through multiple channels, involves a host of new actors, removes existing hierarchies among issues, and reduces the utility of military force. Consequently, globalization reflects a pattern of linkage strategies and transnational networks, while power arises from the ability to set the agenda of international politics and to work within the rules and procedures of international institutions (Keohane, 2002). Meanwhile, the constructivist school challenges observers to consider the power of ideas and knowledge in shaping the international and domestic environment. Because globalization provides for multiple channels of communication other than those previously dominated by the state, the nature of power has become diffuse to the extent that one person can change global politics. An activist like Jody Williams, 1997 Nobel Peace Prize winner, could organize the International Campaign to Ban Landmines and alter the way states perceive their security interests vis-à-vis such weapons. Alternatively, Osama Bin Laden could reshape the agenda of global politics through his attacks on New York and Washington in 2001. In terms of the power of ideas, the rise of US hegemony after World War II succeeded because of the form it took via building cooperative multilateral institutions to promoting ideas of peace, democracy, and free markets (Mandelbaum, 2002). There are three particularly important changes in the nature of power dynamics that are affected by the globalization of the international system: asymmetric power; state power; and the role of people, ideas, and media power. 


\section{Asymmetric Power}

In the globalized international system, the largest powers become magnets for those seeking to promote change in the distribution of power. Ironically, those with the most power are also those who are most susceptible to asymmetrical attacks. For example, in 1993, the United States withdrew from Somalia following the battle of Mogadishu. This was a strategic defeat in that a message was sent that the way to attack the United States was to inflict casualties and to create shock and terror via instant global communication. Al-Qaeda leader Osama Bin Laden has said that he and his movement drew inspiration from the presumed weakness of the USA following the Somalia debacle. Rather than fight a losing conventional battle against the US invasion in 2003, the Iraqi military dissolved into the civilian population, only to re-emerge as a significant guerrilla and terrorist threat months after major combat was declared over by US President George W. Bush. When asymmetrical power is employed, the actual targets that are hit are important, but the real battleground takes place over the waves and networks of television and other globalized means of communication. These means of channeling power make the weak appear and feel strong, thereby creating an incentive to rectify an imbalance of power via asymmetrical means.

The technological dynamics of globalization make asymmetrical power especially dangerous when juxtaposed against the proliferation of weapons of mass destruction. As illicit transnational networks of weapons technology transfers grow, the risk of such proliferation becomes higher and more difficult to prevent. While Brazil, Argentina, Ukraine, and South Africa have given up their nuclear capabilities, the ability to attain weapons of mass destruction remains an important and asymmetrical means of deterring external attack. However, economic incentives to integrate into the global marketplace can also provide reasons for states not to pursue costly and isolating weapons of mass destruction programs. A country like Iran faces a particular challenge in the light of its perceived security requirements. Iran's leaders appear to feel compelled to attain nuclear weapons as a deterrent. However, their quest for nuclear deterrence can undermine economic gains from trading with Western countries - which could lead to internal instability among a new generation of citizens who are exposed to globalization. The situation for a country like North Korea is somewhat simpler because of its lack of exposure to the globalized international system. The leadership in Pyongyang perceives an external threat and is pursuing weapons of mass destruction as an asymmetric deterrent. But the North Koreans do not have access to the globalized economy and thus seem to feel they have nothing to lose by pursuing nuclear weapons. In fact, the pursuit of such systems appears to be the only bargaining leverage North Korea has 
to find the economic means of ensuring long-term regime survival. Of course, in a conflict with the United States, North Korea would be destroyed. However, whether the USA is willing to engage in such a conflict or not would be conditioned on whether the USA wants to risk an asymmetrical retaliatory nuclear response on its territory. Ironically, globalization allows for a proliferating demand for the use of asymmetrical tools to power while simultaneously providing the political-economic tools to foster disarmament.

\section{Rethinking State Power}

Globalization and asymmetrical power dynamics do not eliminate state power, but rather provide additional channels for its expression and accelerate its application. Globalization can be an important tool for large states to enhance their power - especially at the economic level. Globalization also provides alternative avenues for small or weak states to challenge more powerful states or to dissuade them from exploiting existing vulnerabilities. For example, in China the military has studied asymmetric responses to any potential war they might engage in with the United States - including terrorism, drug-trafficking, environmental degradation, and computer virus propagation. While China is developing its conventional military capabilities, some Chinese strategic planners also see networks of globalization and asymmetrical power opportunities as righting an imbalance of military capabilities. When China was confronted with a possible conflict with the United States over Taiwan in 1996, military strategists indicated that 'we realized that if China's military was to face off against the United States, we would not be sufficient .... So we realized that China needs a new strategy to right the balance of power' (Pomfret, 1999). Chinese military analysts see the path to strategic great-power victory coming through the channels of globalization - and the more complex these channels are, the better. Any war between China and the United States would thus be guided in Beijing by 'unrestricted war', which takes 'non-military forms and military forms and creates a war on many fronts' (Pomfret, 1999).

In the case of the 1999 Kosovo war, Belgrade's primary means of dissuading NATO from attacking Serbia was to threaten the mass expulsion of Kosovar Albanians. When NATO went to war, the very ethnic-Albanians it was trying to help suffered severely as over 800,000 people were expelled from Yugoslavia. The Serbs were able to use NATO mistakes combined with media reporting of civilian casualties to effectively get inside the NATO decisionmaking loop. As national preferences conflicted, NATO's rules and decisionmaking procedures made it very difficult for the institution to 
achieve an effective plan for a quick victory. Ironically, however, the broadcast of images of mass deportation on international live television was reminiscent of the holocaust of World War II and bolstered NATO's resolve to win the war. The publicity that $\mathrm{CNN}$ and other globalized communication networks generated became as important as NATO's bombs in terms of winning the war.

As warfighting becomes increasingly reliant on hi-tech capabilities and asymmetrical tactics, it is possible that states could skip generations of military development and instead invest in the futuristic concepts of cyberwar, infowar, and other modern integrated systems. The technological dynamics of globalization can thus become key sources of security competition. Technological advances, however, can also have drawbacks. The United States, which far outpaces even its closest allies in military technology, finds it is no longer effective to fight alongside other countries. To share its technology, even with allies, would expose US military-industrial primacy to international competition enhanced by globalization. Ironically, as the United States advances technologically, it risks being priced out of the global arms trade, thus providing relative gains for European, Russian, and Chinese weapons manufacturers.

While military advantage can increase the incentives to act unilaterally, these incentives are muted by the pressures that globalization places on states to also advance their 'soft power' capabilities and appeal (Nye, 2001). In an era of globalization, states find that their power is determined by other factors than classical military foundations. States that invest in high-skilled and hi-tech education might gain a relative advantage over those that do not. States that fail to invest in soft-power advantages at the domestic level might, for example, become technologically dependent on foreign workers and thus are vulnerable should the latter leave. International elements of soft power include the ability to convince states to cooperate. States must not only be able to compel cooperation; they must attract cooperation via positive incentives such as the appeal of political and/or economic principles and norms. Soft power requires states to work within the new mechanisms of globalization - such as the rules and procedures of international institutions - to build effective coalitions. For example, in pure military measures of power, the USA was able to fight virtually alone in the 2003 Iraq invasion. However, simultaneously, Washington alienated much of the international community. This choice proved to be a significant miscalculation given the costs and risks associated with long-term occupation and rebuilding in Iraq combined with the damage to US prestige from the failure to find evidence of an immediate threat of weapons of mass destruction. Acting alone with military power also meant mostly going it alone on the costs and sustaining $95 \%$ of the casualties.

Effective utilization of soft power in Iraq would have meant being more 
persuasive and working with the international community better before the war, so as to avoid the 'catastrophic peace' - as the situation in postwar Iraq is often derogatorily referred to inside the US military. Had the United States built a true coalition before the war, it would have paid near-term costs in terms of military effectiveness but made long-term postwar gains. Globalization therefore compels states to consider how to exercise both their hard-power and their soft-power capabilities. Given the complex channels of globalization, a higher premium is increasingly put on the power to persuade rather than the power to attack. In a globalized security dynamic, unilateralism creates higher costs to a state's power objectives if the exercise of hard power prompts soft-power balancing by other states or among international public opinion (Pape, 2003).

In an era of globalization, power-balancing persists, but takes on different forms and channels. States can use the principles and norms of international institutions and the rules and procedures by which they work to constrain other states (Kay, 2000). As the 2003 Iraq war demonstrated, a powerful state might not be stopped by an international organization - but it might be constrained significantly. US domestic political pressures required that the United States seek legitimacy for a pre-emptive war. The USA thus spent six months trying to build international consensus through the United Nations. Germany, France, and Russia extracted near-term concessions from the United States - for example, by insisting on the role of UN weapons inspectors through the fall of 2002 and early 2003. However, in the end, they were not able to stop the invasion of Iraq, thus demonstrating the limits of softpower balancing via international institutions. An interesting alternative approach is illustrated by China's decision not to campaign actively against a US invasion of Iraq. If the United States invaded Iraq and succeeded absent China's opposition, China would reap payback gains from the United States. If the United States invaded Iraq and got bogged down, China would have more freedom to explore its strategic interests. With one-half of the US military devoted to Iraq and forced to carry the burden alone, both Washington's hard- and soft-power reserves are significantly depleted.

\section{People, Ideas, and Media Power}

Globalization levels the playing field of international politics in ways that nation-states cannot prevent. Popular movements and the ideas that they advocate via proliferating media networks place public demands on states as well as international institutions to react in ways that they might not otherwise. Consequently, globalization permits certain issues and regions of the world to gain international attention when organized activism combines 
with the impact of modern media technology. The powerless (as measured in traditional terms) can become powerful as control over information and access to knowledge become key areas of power competition (Haas, 1991). This latent power has translated into major international people's movements that have demanded significant international change via issue advocacy. For example, through the 1990s, nongovernmental organizations successfully lobbied the World Bank to alter its loan policy in the underdeveloped world so that development loans would first be given an environmental impact assessment. Public international interest groups including those advocating for the environment and human rights - and labor movements began taking to the streets, with major protests at the 1999 Seattle World Trade Organization (WTO) meetings. While the WTO's legal mandate is only to deal with trade issues, the people in the streets of Seattle forced the leaders of the institution's member-states to acknowledge the relationships between free trade and the environment, labor standards, and human rights. International public movements can constrain states, especially in democracies, and states that ignore the will of global citizens do so at their own peril. Moreover, the proliferation of international interest articulation makes it more difficult for states to plan effectively as they must sift through an increasingly complex agenda.

International hegemonic powers like the United States are especially vulnerable to the ebbs and flows of global public opinion. Should international consumers opt to boycott US goods, stop sending students to US universities, and develop alternative resource bases for technology and service provision, the US economy would be severely damaged. Or, should the major global consumer and resource-producing societies invest in the euro as a preferred global currency over the US dollar, US economic power would be seriously affected - which would also be the case if foreign direct investment began to disappear from the US economy. As 15 million people worldwide gathered in one day to protest the US decision to attack Iraq in early 2003, the scope of potential hostility to US power was made clear. Perhaps even more problematic for a globalization that reflects hegemonic influence - that is, an increasingly 'Americanized' globalization - was a 2002 opinion survey by the Pew Global Attitudes Project, which showed that 54\% of the British and $50 \%$ of the Canadian public - the USA's two closest allies in the world - saw the expansion of US customs and values as a negative phenomenon. In key states allied with the USA in its war on terrorism, such as Egypt and Pakistan, pro-US sentiment was below 10\% (PEW, 2002).

As globalization is increasingly seen as a US-dominated phenomenon, it is likely that the backlash against globalization will take a decidedly anti-US tone. Even when the United States has sought to do good and worked to exercise its soft power positively, it has not always reaped expected gains. For example, international economic sanctions have been seen as a useful 
tool to get authoritarian governments to comply with international norms. However, in 1996, 60 Minutes reporter Leslie Stahl put the following question to Madeleine Albright (who was at the time US ambassador to the United Nations): 'We have heard that a half million children have died. I mean, that's more children than died in Hiroshima. And - and you know, is the price worth it?' To this, Albright responded: 'I think this is a very hard choice, but the price - we think the price is worth it' (Sixty Minutes, 1996). Widely ignored in the United States, Albright's comments were disseminated throughout the Middle East. As journalist Nicholas Kristof observes, US sanctions on Burma have led to some 100,000 people there losing jobs while Burma's dictators stay in power - this in a country where one child in ten dies before their fifth birthday, $44 \%$ of children are malnourished, and $58 \%$ of pregnant women are not receiving adequate medical care. Many of the women who are unemployed as a result of US sanctions have little choice but to earn their living in the sex industry, thus risking exposure to and proliferation of HIV/AIDS (Kristof, 2003). For a country like the United States, which seeks to promote the soft-power appeal of its values and ideas, such contradictions inevitably create resentment in a world where two billion people survive on less than $\$ 2.00$ a day and where the UN estimates that in the year 2015 some $40 \%$ of the world's population will live in areas without drinkable water. These consequences of the exercise of US power are themselves channeled through the international media. Americans see their power as benign. However, the way Washington has exercised power risks undermining the USA's soft-power appeal.

Activism, ideas, and communications shape perspectives on international politics, and the means of globalization dramatize and accelerate these new battlegrounds of power. It is, however, important not to overstate the ability of these new channels of globalization to constrain state action. The rise of global public opinion against the United States in early 2003 did not prevent it from attacking Iraq. Most obviously, if the 11 September 2001 attacks were intended to prompt a retrenchment of US power, one need only look to Afghanistan and Iraq, and the many other states in the world hosting US troops, to see how unsuccessful those terrorist attacks were. To the extent that state behavior is affected by people, ideas, and media power, it is more likely to remain at the margins of state policy. Nevertheless, the new and proliferating channels for public engagement combine with the presence of modern media capabilities to alter the agenda-setting dimension of international security and affect the ways in which states best exercise their power. 


\section{The Globalization of Terror}

Globalization forces states to reconceptualize threats when non-state actors seek to enhance their power via indiscriminant acts of violence - that is, international terrorism. The globalization of terror and resultant fear has strengthened the nation-state. For example, homeland security is a collective good where the nation-state is vital for defense against international terrorism. Interestingly, the means of homeland defense are themselves non-traditional assets, such as police and first responders. Despite this new demand for a strengthening of the nation-state for homeland security, international terrorist organizations exist and compete for power within the networks of globalization. Globalization is thus both a rallying cry for terrorists and the means by which they carry out their actions. The speed with which images of fear can be transferred into the living rooms of citizens around the world radically distributes power in favor of asymmetric tactics. The ability to enhance power by cultivating fear is made clear by statistics that show that while people worry about terrorism and states invest in anti-terrorism measures, terrorism is actually in global decline. The risk of being killed in a terrorist attack is virtually zero for the average citizen (Mueller, 2002). The success at manipulating a global audience with fear helps further terrorist recruitment as individuals are co-opted into a sense of empowerment that they feel from making the strong feel vulnerable. Meanwhile, the media of globalization serves as a force multiplier by carrying the images of fear and destruction that terrorists seek to perpetuate.

Such asymmetric challenges create an immediate demand for the nationstate to provide for homeland security. However, these threats also illustrate the limits up to which a state can provide for security without engaging in the battle for power using the means of globalization with which terrorist networks operate. The rise of global finance, the 24-7 global economy, the ability to hide financial resources in safe havens, the ability to traffic in illicit items, the ability to encode communications with advanced technology, and the growth of transnational ethno-religious communities are key manifestations of the globalized pathways within which terrorists work (Williams, 2003). Such threats require a complex response involving allies, international institutions, adapting the role of intelligence, waging war within the mechanisms of international finance, promoting common standards of international law enforcement, protecting information systems, and providing for detection of weapons of mass destruction (Williams, 2003). Any successful campaign against international terrorism will require getting inside the globalized pathways of terrorism. Asymmetrical attempts to gain power require a response calibrated to the complexity of a globalized security environment.

Over-reliance by states on military power in an era of globalized security 
dynamics can erode the core foundations of what now makes states powerful. As the United States moves beyond a $\$ 400$ billion annual defense budget, it is adding onto its pre-existing force structure, not forcing a major rethinking of its military requirements. For example, the United States continued to plan to spend $\$ 22$ billion on the deployment of untested and unproven missile defense systems in 2004 - which have no value for deterring terrorists. If states know that an inevitable retaliation is coming, they should also be aware that its perpetrators are more likely to utilize a boat or container to deliver a nuclear weapon into a US city via a third-party terrorist organization. It is not clear that the United States understands fully the threat that it confronts: the quest for power by international terrorist groups operating within the networks of globalization. In fact, an overemphasis on the military tool to defeat international terrorism might only breed more international terrorists. While Washington was dramatically increasing its defense budget, the Council on Foreign Relations (2003) published a comprehensive study demonstrating that the US underfunds homeland security by nearly $\$ 90$ billion.

Investment in the traditional means of military capability remains a vital national interest. Overinvestment or investment in the wrong resources, however, can undermine national security as new threats go unnoticed or are insufficiently appreciated. This is especially true for great powers that advance their hegemony via military power. While expansive great powers invest in securing their periphery, they can erode the economic foundations of their power at home (Gilpin, 1981). The United States is in danger of overinvesting in the wrong requirements for security, while simultaneously diminishing its global soft-power appeal.

In 2003, the United States was preparing to invest $\$ 150$ billion for one year of warfare and rebuilding in Iraq - a relatively well-off country sitting on top of one of the world's largest oil supplies. Most likely, the USA would have to maintain and finance a substantial military presence in Iraq for many years to come. Meanwhile, international AIDS activists have had to plead with the USA to spend even $\$ 3$ billion of the $\$ 15$ billion it has promised to combat AIDS internationally. According to UNAIDS estimates, some eight million people worldwide have died of this disease and over 30 million are infected with HIV - ravaging populations in Africa, where 7,000 are believed to die daily. Gauged in security terms, the minimal investment in combating AIDS as a transnational disease is shortsighted, as Africa is precisely where failed states can provide new safe harbors for terrorist networks. Additionally, the primary rationale for a pre-emptive war in Iraq was to ensure that Iraq could not develop weapons of mass destruction that might leak out into the hands of terrorists via the pathways of globalization. However, public reports indicated before the war that Iraq would only be able to develop such materials if it could gain access to key international resources (International 
Institute for Strategic Studies, 2002). The primary source for the leakage of nuclear material would most likely be from within the former Soviet Union. Ironically, given the $\$ 150$ billion one-year expenditure in Iraq, the (US Department of Energy-sponsored) Baker-Cutler Commission estimated in 2001 that securing the nuclear weapons and storage facilities in the former Soviet Union could be accomplished with a total expenditure of $\$ 30$ billion over a ten-year period (Baker \& Cutler, 2001).

\section{Conclusion}

This overview of globalization illustrates important trends in international security that states ignore at their peril. International relations theory continues to serve as an excellent signpost for assessing the nature of an increasingly globalized world. Moreover, the core concept of power remains the most important independent variable shaping international outcomes. This conclusion mostly supports the realist school of international relations, which has been challenged by the alternative approaches precisely for its overemphasis on systems structure and power. However, defining the independent variable of power has become more complicated for realists as power takes on new forms and is exercised through new channels. Realists must therefore readjust the definition of power to account for the new avenues of power that globalization provides. Globalization is not a guarantee of peace - nor is it a precursor of conflict. Rather, globalization is a means through which new manifestations of power are exercised. The power to affect which direction the world will take in the 21st century lies with a new generation of leaders and strategic thinkers who are, themselves, a product of this evolving global era.

* Sean Kay is Associate Professor of Politics and Government and Chair of the International Studies Program at Ohio Wesleyan University. He is also a non-resident fellow at the Eisenhower Institute in Washington, DC. His most recent book is the co-edited volume Limiting Institutions: The Challenge of Eurasian Security Governance (Manchester University Press, 2003).

\section{References}

Baker, Howard, \& Lloyd Cutler, 2001. 'An Unacceptable Risk', Washington Post, 11 January.

Brown, Seyom, 1998. 'World Interest and the Changing Dimensions of Security', in Michael Klare \& Yogesh Chandrani, eds, World Security: Challenges for a New Century. New York: St. Martin's Press (1-17). 
Clark, Ian, 1999. Globalization and International Relations Theory. Oxford: Oxford University Press.

Claude, Inis L., 1962. Power and International Relations. New York: Random House.

Council on Foreign Relations, 2003. Emergency Responders: Drastically Underfunded, Dangerously Unprepared. New York: Council on Foreign Relations.

Gilpin, Robert, 1981. War and Change in World Politics. Cambridge: Cambridge University Press.

Glaser, Charles \& Chaim Kaufman, 1998. 'What is the Offense-Defense Balance and How Can We Measure It?', International Security 22(1): 44-82.

Goldstein, Judith \& Robert O. Keohane, eds, 1993. Ideas and Foreign Policy: Beliefs, Institutions and Political Change. Ithaca, NY: Cornell University Press.

Haas, Ernst B., 1991. When Knowledge Is Power: Three Models of Change in International Organizations. Berkeley, CA: University of California Press.

Huntington, Samuel, 1996. The Clash of Civilizations. New York: Touchstone.

International Institute for Strategic Studies, 2002. IISS Strategic Dossier: Iraq's Weapons of Mass Destruction, A Net Assessment. London: International Institute for Strategic Studies.

Kay, Sean, 2000. 'What is a Strategic Partnership?', Problems of Post-Communism 47(3): $15-24$.

Keohane, Robert O., 1989. International Institutions and State Power. Boulder, CO: Westview.

Keohane, Robert O., 2002. Power and Governance in a Partially Globalized World. New York: Routledge.

Keohane, Robert O. \& Joseph S. Nye, 2001. Power and Interdependence, 3rd edn. New York: Addison Wesley Longman.

Kristof, Nicholas, 2003. 'Sanctions Don't Work', International Herald Tribune, 10 November.

Kugler, Richard L. \& Ellen L. Frost, eds, 2001. The Global Century: Globalization and National Security Volume I and II. Washington, DC: National Defense University Press.

Levy, Jack, 1983. War in the Modern Great Power System, 1945-1975. Lexington, KY: University Press of Kentucky.

Mandelbaum, Michael, 2002. The Ideas that Conquered the World: Peace, Democracy, and Free Markets in the 21st Century. New York: Public Affairs.

Mearsheimer, John J., 1995. 'The False Promise of International Institutions', International Security 19(3): 5-49.

Mearsheimer, John J., 2001. The Tragedy of Great Power Politics. New York: W. W. Norton.

Morgenthau, Hans J., 1978. Politics Among Nations, 3rd edn. New York: Knopf.

Mueller, John, 2002. 'Harbinger or Aberration: A 9/11 Provocation', The National Interest 69(3): 45-50.

Nye, Joseph S., 2001. The Paradox of American Power. Oxford: Oxford University Press.

Pape, Robert, 2003. 'The World Pushes Back', Boston Globe, 23 March.

PEW Research Center for the People and the Press, 2002. PEW Global Attitudes Project. Washington, DC: Pew Publications.

Pomfret, John, 1999. 'China Ponders New Rules of "Unrestricted War"', Washington Post, 8 August.

Sixty Minutes, 1996. 'Punishing Saddam', 21 May.

Tangredi, Sam J., ed., 2002. Globalization and Maritime Power. Washington, DC: National Defense University Press.

Van Evera, Stephen, 1999. Causes of War: Power and the Roots of Conflict. Ithaca, NY: Cornell University Press.

Walt, Stephen M., 1987. The Origins of Alliances. Ithaca, NY: Cornell University Press. 
Waltz, Kenneth N., 1979. Theory of International Politics. New York: Random House.

Wendt, Alexander, 1992. 'Anarchy Is What States Make of It: The Social Construction of Power Politics', International Organization 46(2): 391-425.

Wendt, Alexander, 1994. 'Collective Identity Formation and the International State', American Political Science Review 88(2): 384-396.

Wendt, Alexander, 1999. Social Theory of International Politics. Cambridge: Cambridge University Press.

Williams, Phil, 2003. 'Eurasia and the Transnational Terrorist Threats to Atlantic Security', in James Sperling, Sean Kay \& S. Victor Papacosma, eds, Limiting Institutions: The Challenge of Eurasian Security Governance. Manchester: Manchester University Press. 